NBER WORKING PAPER SERIES

\title{
PERSONAL INCOME TAXES AND THE GROWTH \\ OF SMALL FIRMS
}

\author{
Robert Carroll \\ Douglas Holtz-Eakin \\ Mark Rider \\ Harvey S. Rosen
}

Working Paper 7980

http://www.nber.org/papers/w7980

\section{NATIONAL BUREAU OF ECONOMIC RESEARCH 1050 Massachusetts Avenue \\ Cambridge, MA 02138}

October 2000

We thank the Center for Policy Research at Syracuse University, the Center for Economic Policy Studies at Princeton, and the National Science Foundation for their support. We are grateful for useful comments from Gerald Auten, Dan Black, David Blanchflower, Don Bruce, Jeffrey Kling, James Poterba, and participants in the Tax Policy and the Economy Conference. We also thank Esther Gray for her help in preparing the manuscript. The views expressed in this paper are those of the authors and not necessarily those of the National Bureau of Economic Research.

(C) 2000 by Robert Carroll, Douglas Holtz-Eakin, Mark Rider and Harvey S. Rosen. All rights reserved. Short sections of text, not to exceed two paragraphs, may be quoted without explicit permission provided that full credit, including (C) notice, is given to the source. 
Personal Income Taxes and the Growth of Small Firms

Robert Carroll, Douglas Holtz-Eakin, Mark Rider and Harvey S. Rosen

NBER Working Paper No. 7980

October 2000

JEL No. J23, H24, H25

\section{ABSTRACT}

This paper investigates the effect of entrepreneurs' personal income tax situations on the growth rates of their enterprises. We analyze the personal income tax returns of a large number of sole proprietors before and after the Tax Reform Act of 1986 and determine how the substantial reductions in marginal tax rates associated with that law affected the growth of their firms as measured by gross receipts. We find that individual income taxes exert a statistically and quantitatively significant influence on firm growth rates. Raising the sole proprietor's tax price (one minus the marginal tax rate) by 10 percent increases receipts by about 8.4 percent. This finding is consistent with the view that raising income tax rates discourages the growth of small businesses.

\section{Robert Carroll}

Office of Tax Analysis

Main Treasury Building

$15^{\text {th }}$ and Pennsylvania Avenue

Washington, DC 20220

email: robert.carroll@do.treas.gov

Mark Rider

Department of Economics and Finance

Kennesaw State University

1000 Chastain Road

Kennesaw, GA 30144

email: mrider@gsu.edu
Douglas Holtz-Eakin

Department of Economics

Syracuse University

Syracuse, NY 13244-1020

email: djheakin@maxwell.syr.edu and NBER

Harvey S. Rosen

Department of Economics

Princeton University

Princeton, NJ 08544

email: hsr@princeton.edu

and NBER 


\section{1. $\underline{\text { INTRODUCTION }}$}

The health and vitality of entrepreneurial enterprises is a matter of substantial policy concern. In this context, a good deal of attention has been focused on the question of whether the tax system impedes the creation and growth of small firms. Certainly, many entrepreneurs believe that it does:

As an entrepreneur, I experience first hand the horrors of our tax system. It has grown into a monstrous predator that kills incentives, swallows time, and chokes the hopes and dreams of many (Kemp Commission, as quoted in Engen and Skinner [1996]).

In fact, however, not much is known about how an entrepreneur's tax situation affects the growth of his or her business. ${ }^{1}$ The purpose of the present paper is to investigate this issue. We analyze the income tax returns of a large group of sole proprietors before and after the Tax Reform Act of 1986 (TRA86) and determine how their firms' growth rates were affected by that law's substantial reductions in marginal tax rates. In effect, we seek to find out whether the firms with the largest decreases in tax rates grew the fastest.

Section 2 provides a framework for the analysis. We address the question of why, on $a$ priori grounds, one might expect a sole proprietor's personal tax situation to affect the growth of his or her enterprise. Section 3 describes the data used in our analysis. Section 4 presents our statistical model and results. To anticipate the conclusions, we find that individual income taxes exert a substantial influence on firm growth rates. For example, raising the entrepreneur's "tax price" (one minus the marginal tax rate) by 10 percent increases firm size as measured by gross receipts by 8.4 percent - an elasticity of 0.84 . Section 5 concludes with a summary and suggestions for future research. 


\section{2. $\quad$ CONCEPTUAL FRAMEWORK}

In this section we review what economic theory has to tell us about the impact of taxes on the growth of entrepreneurial enterprises. As it turns out, the bottom line is that theory yields no unambiguous predictions. Nevertheless, the analysis identifies the sources of the ambiguity and provides a useful framework for interpreting the empirical results. Technical details are included in the Appendix.

To begin, focus on the decisions confronting an entrepreneur who will remain in business indefinitely (i.e., momentarily ignore the impact of taxes on business survival). Next suppose the

entrepreneur faces a reduction in his marginal tax rate. ${ }^{2}$ This generates two conflicting effects. First, with a lower tax bite there is an increased reward for effort devoted to the enterprise. Typically, one would assume that this raises the entrepreneur's exertions. At the same time, however, the old level of effort translates into greater after-tax profits. Thus, the entrepreneur may be tempted to enjoy these fruits by living a little better-consuming more goods and, also, leisure. This is the familiar conflict of substitution and income effects, and from introspection alone, the net effect is unclear. Theory does not carry a strong prediction about even the direction of the impact of taxes on entrepreneurial efforts.

This fundamental ambiguity spills over into the effect of taxes on the myriad activities of the entrepreneurial venture. The entrepreneur produces output by combining his effort with purchased inputs such as hired labor, capital, materials, and so forth. If taxes alter the level of entrepreneurial effort, he may respond by re-balancing the mix of other inputs. The nature of the re-balancing, however, is not obvious. Some inputs are substitutes for owner's effort (one could hire a manager to supervise the operation) while others are complements (if the owner chooses to close on weekends, there is no need for an employee to handle the cash register). Hence, just 
like the owner's effort, the sign of the impact of taxes on the demands for the other components of the production process is ambiguous. If the effect on the usage of all inputs (including entrepreneurial effort) is ambiguous, so is the effect on output, and assuming the price of output is unaffected, so is the effect on receipts. It follows that the overall impact on the size of the business is theoretically ambiguous.

Of course, as is well-known, small businesses both start-up and fail at significant rates. Hence, we must also consider the implications of a tax reduction on the relative attractiveness of being an entrepreneur versus working in a wage and salary job. One might suppose that an income tax is neutral in this respect because income from all activities is taxed at the same rate. As shown formally in the Appendix, however, the net impact on the choice between entrepreneurship and a wage-salary job is unclear. The ambiguity arises because the decision is not exclusively determined by financial considerations, but rather by overall levels of utility in each activity. In each case, a small reduction in taxes would raise after-tax earnings. This would, in turn, translate into higher consumption. However, the associated change in utility in each mode depends on its marginal utility of consumption and there is no reason for the marginal utilities to be the same.

Our discussion follows the tradition of viewing impacts on relative prices as the main mechanism through which taxes affect economic outcomes. However, price incentives may not be the only channel by which taxes affect entrepreneurs. Specifically, to the extent that the entrepreneur is liquidity constrained, ${ }^{3}$ the increase in cash flow associated with a decrease in taxes will increase the demand for capital, which in turn will increase the enterprise's output and receipts. Since the price incentive and liquidity constraint stories are not mutually exclusive, we will not attempt to disentangle them in our analysis. 
Another important question that is finessed in the simple model is which tax rate is relevant? We have assumed that the relevant tax rate is that on ordinary income. In contrast, much of the popular discussion of this matter has focused on the capital gains rate. A writer in the Wall Street Journal, for example, stated that he was "of a class of entrepreneurs who feel shackled by the high capital gains tax in our country" and that his "companies would have grown better and faster" with a lower capital gains tax (Rigby [1996, p. A18]).

To think about this matter, consider a variety of scenarios. In the first, an entrepreneurwe'll call her Smith—runs a simple consulting business and reports her income on Schedule C. Her only input is her time, and her receipts consist of payments for her advice. In this setting, there is no vehicle for "retained earnings" or "plowing funds back into the business" and the ordinary tax rate is the relevant one.

Suppose now that Smith not only uses her own time, she also purchases paper and hires an assistant. These purchased inputs are fully deductible against her receipts, but do not change the basic story. The ordinary income rate applies to the enterprise's net income.

Suppose further that Smith purchases capital assets, such as computers, office equipment, or even a structure to house her burgeoning business. If so, to the extent that her annual investment is under $\$ 25,000$, it is fully deductible ("expensed") in the year of purchase. ${ }^{4}$ Thus, the ordinary income tax rate is the relevant rate for determining the net cost of the investment. To the extent that investment exceeds $\$ 25,000$, it must be depreciated; if so the value of the depreciation allowances in any given year will depend on that year's ordinary income tax rates.

The assets generate income for the firm, which is taxed at ordinary rates on schedule C. The assets can also generate income for the firm if they appreciate in value and Smith sells them. If so, the appreciated-value component of such assets could be taxed at either the capital gains 
rate or the ordinary income tax rate. The key issue is whether an asset qualifies as a "capital asset" for the business. Capital assets are all assets except the company's "stock in trade" (inventory property), accounts receivable, copyrights and musical/literary materials, commodities, hedges and supplies. Thus, for example, if an art dealer sells a painting from inventory, then any appreciation in value is taxed as ordinary income. ${ }^{5}$ It is certainly possible, then, that for certain sole proprietors the capital gains tax rate may be relevant in this context. We have no way of determining the importance of this possibility. It is interesting to note, however, that in any given year, considerably fewer than one-half of sole proprietors make any capital investments at all [Carroll, Holtz-Eakin, Rider, and Rosen 2000b, p. 431].

In the next scenario, Smith sells the company altogether. Suppose she sells the company for $\$ 100,000$ in cash. The sales price will reflect not only appreciation of capital assets, but also intangible assets such as good will, going concern value, know-how, etc. For tax purposes, she subtracts her basis in the company from the $\$ 100,000$, and the difference is taxed at the capital gains rate. We have no direct evidence relating to the importance of such transactions. However, in a recent careful analysis of 1985 data on capital gains realizations, sales of business assets by sole proprietors were not sufficiently large even to merit attention as a separate item (Auten and Wilson [1999]).

Finally, suppose that Smith "goes public" with her firm. The key thing to realize here is that going public is not a taxable event per se. At the time of an initial public offering, the sole proprietor receives shares in the new corporation, and the capital gains tax is not paid until such time as those shares are sold. At that time, the capital gains tax rate is applied to the difference between the sales of stock and Smith's basis in the stock. An initial public offering (IPO) is just one of several ways in which a business can be sold in whole or in part via some type of tax-free exchange. For example, Smith might receive stock in the acquiring company. For our purposes, 
the story is basically the same. The capital gains rate is not relevant until such time as the newlyacquired stock is sold. If the stock is not sold before the owner's death, the capital appreciation may never be taxed at all.

Taking all these scenarios together, what can we conclude about the relevant tax rate? The theoretically ideal tax rate is a weighted average of the contemporaneous ordinary income tax rate and the expected present discounted value of the relevant capital gains tax rate for that component which eventually is accorded capital gains treatment. However, the capital gains rate may or may not ever be applicable, and if so, one does not know how many years in the future. The expected present discounted value of the relevant capital gains rate for a sole proprietor would in most cases probably be quite small, especially given that the expectation is taken over states of the world that include failure of the enterprise. In light of all these considerations, as a practical matter, the ordinary tax rate seems the appropriate one to use in the analysis of the behavior or sole proprietors.

\section{DATA}

Our data are drawn from the Statistics of Income Individual Tax Files for 1985 and 1988, a panel consisting of 62,159 tax returns for taxpayers present in both years. These files contain detailed information on taxpayers' income and deductions taken from their Form 1040. We excluded from our sample taxpayers filing as heads-of-household, married filing separately, surviving spouses, taxpayers with duplicate (and likely erroneous) returns in either year, and those who reported income on a fiscal year basis. This left us with 56,701 returns.

We next selected only individuals aged 25 to 55 in 1985 in order to avoid complications that would arise because of younger sole proprietors' labor market entry decisions and older sole proprietors' impending retirements. This further reduced the sample size by 20,141 to 36,360. 
We also eliminate taxpayers who were subject to the alternative minimum tax (AMT) as our tax calculator did not permit accurate computations of all taxpayers' marginal tax rates under the AMT. $^{6}$ The result was a sample of 32,662 tax returns. Finally, we eliminated dependent returns and those who changed filing status between 1985 and 1988. The end result of this process is a sample of 31,034 returns.

Our basic sample consists of individuals who filed a Schedule C in both 1985 and 1988, of whom there are $6,817 .^{7}$ In principle, results drawn from such a sample might be subject to selectivity bias - sole proprietors who survive until 1988 may not be a random sample of the 1985 group. Our econometric procedure, described below, attempts to take this selectivity problem into account.

Table 1 summarizes how the income-generating activities of the sample of 8,675 individuals who filed a Schedule C in 1985 changed from 1985 to 1988 . The first row shows the proportion of sole proprietors who exited that organizational form between 1985 and 1988. It indicates that 8.59 percent of the individuals who had Schedule C income but no wage in 1985 income exited by 1988. For individuals who reported both Schedule C income and wage income in $1985,21.2$ percent were no longer sole proprietors by 1988. The remaining four rows provide information on transitions from sole proprietorships to particular types of income-generating activity. The second row focuses on transitions to wage-earning without any "business income" (defined as income from a partnership or Subchapter S Corporation). 2.9 percent of the individuals who had only schedule C income in 1985 and 12.6 percent of those who were initially sole proprietors and wage-earners made such a transition.

The figures in parentheses show the proportion of individuals in the column who made the type of transition indicated in the row. For example, of the individuals with Schedule C income only in 1985 who then exited self-employment, 33.8 percent became wage-earners only. 
The third, fourth, and fifth rows provide analogous information for exits from sole proprietorships to business income only, wage income and business income, and neither wage income nor business income ("retirement"), respectively.

Taken as a whole, Table 1 indicates that the overall exit rate is much lower for those returns that have only schedule $\mathrm{C}$ income. Also, exits from sole-proprietorship are split roughly evenly between exits to another business form, wage-earning, and both business and wageearning. A smaller fraction retires. Comparing across columns, for those who begin with some wages in addition to Schedule $\mathrm{C}$ income (recall, for joint-filers these may be the earnings of the spouse), there is a much greater propensity to move to strictly wages and wages plus business, and a lower propensity to move to purely business.

Our sole proprietors have much higher incomes than taxpayers as a whole, a finding that is consistent with earlier research. In 1985, the mean Adjusted Gross Income (AGI) in our sample of sole proprietors was $\$ 177,267$; the mean for all tax returns was $\$ 22,683$. Also consistent with previous research (see, for example, Hamilton [2000]) is the tremendous variation in income among sole proprietors - the standard deviation of AGI was \$1,845,269. The distribution of sole proprietors' incomes is also very skewed; median AGI was only $\$ 54,797$. Not surprisingly, the key components of AGI exhibited qualitatively similar patterns. Mean wages and salaries on the returns were $\$ 116,572$ (s.d. $=\$ 461,994)$, with a median of $\$ 25,413$. Mean capital income (the sum of interest and dividends) was $\$ 50,140$ (s.d. $=\$ 353,160)$, with a median of $\$ 2,197$. In our context, it is particularly interesting to note the dispersion in net schedule $\mathrm{C}$ income - the mean in our sample was $\$ 95,726$ (s.d. $=\$ 618,850)$, but the median only $\$ 6,593$.

As is well known, our sample period coincides with a general widening of the income distribution. For example, in the tax-filing population the cutoff for the bottom 25 percent of the 
distribution of modified adjusted gross income ${ }^{8}$ was $\$ 7,962$ in 1985 . By 1988 , this grew only 1.7

percent to $\$ 8,100$. In contrast, the cutoffs for the $90^{\text {th }}$ percentile, $95^{\text {th }}$ percentile, and $99^{\text {th }}$

percentile grew 12.6 percent, 14.5 percent, and 28.4 percent, respectively.

Among sole-proprietors, this widening is less pronounced and focused among those at the lower end of the distribution. For example, among "survivors" (those who were sole-proprietors in both 1985 and 1988) who started in the bottom 25 percent in 1985, mean modified AGI fell by 14.9 percent. In contrast, the mean growth rates in the other quartiles as well as the top 5 percent were positive and tightly bunched between 9.4 percent and 11.2 percent. In short, with the exception of the lowest quartile, income growth among sole proprietors was fairly even throughout the income distribution. Thus, it is unlikely that our results will be driven by autonomous growth in the upper tail of the income distribution. ${ }^{9}$

How large are enterprises owned by sole proprietors? The size of an enterprise can be measured in several ways, including number of employees, units of output produced, and revenues. Various measures appear in the literature. Gentry and Hubbard [1998] focus on gross receipts. On the other hand, Evans [1987] studies employment, although he reports that analyses of firms' sales and employment growth rates yield similar results (p. 659). Tax return data include information only on revenues, so they are the focus of our analysis. ${ }^{10}$ Specifically, we use gross receipts from line 1(a) of Schedule C. Of course, two firms with the same gross receipts could be in very different financial health depending on their costs. Nevertheless, we choose to focus on gross rather than net receipts because tax data do not include information on economic costs and hence do not allow an economically meaningful measure of net receipts.

Regardless of the particulars of our measure, the sole-proprietors in our sample constitute an important component of entrepreneurial economic activity. According to the Bureau of Economic Analysis, national income in 1985 was \$3,380.4 billion, of which $\$ 2,769.9$ billion (82 
percent) was attributable to domestic business income. The Internal Revenue Service's Statistics of Income (SOI) estimates that non-farm sole proprietors reported gross receipts of $\$ 540$ billion, or approximately 20 percent of domestic business income in 1985.

Based on SOI sample weights, our original sample of 62,159 returns reported gross receipts of $\$ 473.8$ billion -88 percent of the SOI total. The process of sample exclusions lowers the economic activity represented by the sample, but it remains significant. For example, our basic sample of 8,675 returns accounts for 59 percent ( $\$ 320.8$ billion) of the SOI total (those with positive receipts in both 1985 and 1988 account for 49 percent, or \$266 billion).

Using another measure of their importance, the wage bill—payments by sole-proprietors to hired labor_-yields a very similar pattern. Our basic sample of 8,675 returns comprises 62 percent (\$266 billion) of the SOI estimate of total wage payments by sole-proprietors. By either measure, our sample accounts for a significant proportion of entrepreneurial activity.

An important implicit assumption in this discussion is that we can identify soleproprietors as "entrepreneurs." Is this sensible? In the nonstatistical literature on this topic, entrepreneurs are typically identified by their daring, risk-taking, animal spirits, and so forth. However, statistical work forces us to settle for more prosaic, observable criteria for classifying someone as an entrepreneur. With tax return data, the most sensible proxy for "entrepreneurship" is the presence of a Schedule $\mathrm{C}$ in the return. ${ }^{11}$

It has been suggested that the presence of Schedule $\mathrm{C}$ is more indicative of tax-sheltering activity than entrepreneurial activity. For example, some economists may report their consulting income and honoraria on Schedule $\mathrm{C}$ solely in order to be eligible for certain deductions. However, data from the 1985 Statistics of Income suggest that such personal service activities are undertaken by only a small proportion of Schedule C filers, about 16 percent. $^{12}$ And surely at least some of these activities reflect classical entrepreneurial behavior. 
One might be tempted to implement an algorithm for identifying which Schedule $\mathrm{C}$ filers are "serious" entrepreneurs. For example, one could require that business income be above some threshold level. But many start-up enterprises have low or even zero receipts. Another possibility is that the ratio of Schedule $\mathrm{C}$ income to earned income be above some threshold. But as already suggested, "serious" entrepreneurs can have low incomes from their enterprises. Further complications result from using annual data. A serious entrepreneur who starts his or her business late in the year is likely to resemble a full-year, but non-serious, entrepreneur.

We conclude that trying to weed out ersatz entrepreneurs from the population of Schedule C filers is not likely to be terribly fruitful. Nevertheless, below we experiment a bit with alternative thresholds for business revenues as criteria for being classified as an entrepreneur, and find that they have no serious impact on our substantive results.

\section{4. $\quad$ STATISTICAL MODEL AND RESULTS}

\subsection{Econometric Setup}

Our goal is to estimate the determinants of the rate of growth of sole proprietors' receipts between 1985 and 1988. As we discussed in Section 2, the growth rate depends upon the tax rate facing the entrepreneur and the parameters of his utility and production functions. Given these considerations, an appropriate empirical specification posits that the change in the logarithm of receipts between 1985 and 1988 is a function of the reform-induced change in the "tax price"defined to be 1 minus the marginal tax rate - and variables that are related to the entrepreneur's preferences and technology. Specifically, we assume that the growth rate of gross receipts, $\Delta \ln ($ GRECEIPTS $)$, is

$$
\Delta \ln (\text { GRECEIPTS })=\alpha_{0}+\alpha_{1} \Delta \ln (T A X P R I C E)+X_{85} \beta+\varepsilon
$$


where $\Delta \ln ($ TAXPRICE $)=\left[\ln \left(1-\tau_{88}\right)-\ln \left(1-\tau_{85}\right)\right]$ and $\tau_{s}$ is the entrepreneur's marginal tax rate in year $s ; X_{85}$ is a vector of characteristics of the entrepreneur as of 1985 (which reflect differences in utility function parameters) and of the entrepreneur's industry (which reflect differences in production function parameters); and $\beta$ is the associated parameter vector.

An important issue related to equation (4.1) is what variables to include in the $X_{85}$-vector. Tax returns do not contain as rich a set of personal variables as some other data sets, but several useful controls are available. These variables, along with their means and standard deviations, are included in Table 2. Age is listed because it is related to one's experience in the job market and human capital accumulation; hence, it affects the entrepreneur's production function. Age also may affect the individual's risk aversion and hence, the utility function. Previous research on entrepreneurial decision making suggests that a quadratic term in age is also appropriate. ${ }^{13}$ We include marital status and the number of dependents given the possibility that they may affect the entrepreneur's leisure-consumption preferences and risk-aversion.

We include capital income as a measure of the individual's assets, which should affect entrepreneurial decision making in the presence of capital market constraints. ${ }^{14}$ However, one should note that tax return data on capital income are quite poor. Our variable is the sum of reported dividends and interest; it omits capital gains and municipal bond interest, inter alia. ${ }^{15}$ Hence, one must be cautious in interpreting the coefficient on this variable as a test of the liquidity constraint hypothesis. Finally, using the principal business codes reported on Schedule C, we develop a set of dichotomous industry variables. These are intended to take into account industry-specific effects, such as the fact that demand patterns, the parameters of the production technology, and profitable opportunities differ across industries.

A second major issue associated with equation (4.1) is the potential endogeneity of the tax price variable. Marginal tax rates, of course, vary with taxable income. As receipts go up, 
taxable income increases, and so does the marginal tax rate, ceteris paribus. This may induce a spurious negative relationship between $\triangle \ln (T A X P R I C E)$ and the growth of receipts, another manifestation of a problem ubiquitous in investigations of the behavioral effects of taxation (see Feenberg [1987]). As in other settings, a remedy is to estimate the equation using instrumental variables, which requires that we find a variable (or variables) that is correlated with $\Delta \ln (T A X P R I C E)$ but is unlikely to be correlated with the error term.

We construct an instrumental variable that takes advantage of the most prominent feature of our data: the exogenous change in marginal tax rates due to TRA86 itself. To begin, we compute each individual's marginal tax rate using the data and tax law for $1985 .{ }^{16}$ Next we compute each individual's marginal tax rate using the data for 1985 (inflated to 1988 levels), but employing the tax law for 1988. Clearly, the change between the 1985 and the 1988 tax rates computed in this fashion is due entirely to modifications of the tax code. Essentially, this procedure removes the endogenous component of tax rate movements from $\triangle \ln (T A X P R I C E)$, leaving only the part due to the exogenous change in the tax law associated with TRA86. ${ }^{17}$

A possible concern with this strategy is based on the notion that all of the tax reductions associated with TRA86 accrued to high-income individuals. If such individuals are somehow different in unobservable ways from the rest of the sample, then the change in the tax price might simply be proxying for these unobservable differences. To think about this issue, it is useful to begin by noting that, in fact, the 1986 law changed tax rates for virtually everyone and actually increased marginal rates at the low end. Also, it altered many of the provisions that influence marginal tax rates such as those relating to medical expenses, unreimbursed business expenses, and the two-earner deduction. In short, the characterization of TRA86 as affecting only the tax prices of high-income individuals is inaccurate. 
That said, it is of some interest to document how much of the variation in the change in the tax price comes from various segments of the income distribution. To investigate this issue, we divided the sample into quintiles based on 1985 income, and then examined the percentage change in tax price by quintile. As expected, we found that the "typical" (i.e., mean or median) change in the tax price went up with income. However, the standard deviation of the percentage change was remarkably similar across quintiles. ${ }^{18}$ Hence, identification of the tax price coefficient is not coming exclusively from the high-income part of the sample.

The fact that our sample consists of individuals who were sole proprietors in both 1985 and 1988 raises a third issue. Survival as a sole proprietor is not a random process; hence, estimates of equation (4.1) may be rendered inconsistent by selectivity bias. ${ }^{19}$ We take advantage of the technique suggested by Heckman [1979] to deal with this problem. Specifically, using the sample of individuals who were sole proprietors in 1985, we estimate a probit equation of the probability that the individual was still a sole proprietor in 1988 , and then augment equation (4.1) with the inverse Mill's ratio associated with the probit. ${ }^{20}$ A complication arises because the change in the log of the tax price is endogenous in the probit equation as well as the receipts growth equation. We therefore employ instrumental variables in both equations. This insures consistent estimates of the parameters, but complicates the computation of consistent standard errors. We implemented a bootstrapping procedure to deal with this problem, estimating the system 100 times and computing the empirical variance-covariance matrix of the parameter estimates. ${ }^{21}$

\subsection{Basic Results}

To begin, we present in column (1) of Table 3 the estimates of the parameters of equation (4.1), computed using instrumental variables and correcting for selectivity bias as outlined above. From our standpoint, the key coefficient is that on $\triangle \ln (T A X P R I C E)$, which is positive, 
and exceeds its standard error by a factor greater than 5.5. Thus, the greater the percentage increase in a sole proprietor's tax price between 1985 and 1988, the greater the increase in the size of his or her business. This resolves the theoretical ambiguity with respect to the effect of the tax price that we discussed in Section 2. Given that the equation is in log-log form, the coefficient on the tax price variable is essentially the elasticity of receipts with respect to the tax price. Our estimate implies an elasticity of 0.84 . This suggests, for example, that a decrease in the marginal tax rate levied on a sole proprietor from 50 percent to 33 percent would lead to an increase in his receipts by about 28 percent. While "large" effects are in the eye of the beholder, it appears that marginal tax rates have a substantial effect on the growth of entrepreneurial enterprises.

Turning now to the other right-hand-side variables, one finds that both the linear and quadratic terms on age are insignificant. Similarly, the other indicators of the individual's economic and demographic situation do not exert statistically significant impacts, a finding consistent with earlier studies that look at the evolution of various aspects of entrepreneurial enterprises (Holtz-Eakin, Joulfaian, and Rosen [1994a] and von Praag and van Ophem [1994]). ${ }^{22}$ However, industry is a statistically significant variable. In particular, entrepreneurs engaged in the manufacturing and service sectors experienced greater revenue growth than their counterparts in other sectors. ${ }^{23}$ Finally, the coefficient on the inverse Mill's ratio is positive and statistically significant, suggesting (reasonably) that unobserved characteristics that affect the growth of entrepreneurial enterprises and their survival are positively correlated.

An interesting question is whether the positive effect of the tax price on firm growth depends on the presence of the other covariates. This question is particularly cogent given that some of the right-hand-side variables, such as marital status, might be correlated with business success. To investigate this possibility, we re-estimated equation (4.1) with only a constant and 
$\Delta \ln (T A X P R I C E)$. The results are reported in column (2) of Table 3. The coefficient remains positive, of similar magnitude, and statistically significant. Hence, the size and character of the tax effects in column (1) are not artifacts of a correlation between tax rates and other variables.

\section{$4.3 \underline{\text { Alternative Specifications }}$}

We subjected our equation to a variety of checks to determine whether the estimated relationship is sensitive to the data or specification. To begin, we included the 1985 value of family wage and salary earnings. More than one interpretation of this variable is possible. To the extent that earnings are attributable to the entrepreneur's spouse, they may create an income effect for the entrepreneur. To the extent that they are attributable to the entrepreneur, they may be an indicator of the cost of time that is spent in sole-proprietorship activity. If so, they are also likely to be endogenous, the primary reason for not including earnings in the baseline specification reported in column (1) of Table 3. The results when earnings are included appear in column (3) of Table 3 . Its estimated coefficient is negative ( -0.186 with a standard error of 0.0831). Importantly, the inclusion of the earnings variable had essentially no impact on the character of the tax-price results - the coefficient is 0.93 with an estimated standard error of 0.16 .

An important feature of TRA86 is that it embodied changes in the tax base as well as in marginal tax rates. For example, the itemized deduction for state sales taxes was eliminated. Thus, the tax reform generated changes in after-tax income. The theoretical framework in Section 2 suggests that, ceteris paribus, such "tax-base effects" might affect receipts by altering the entrepreneur's own labor supply and his demand for other factors.

To investigate this possibility, we augmented the specification in Table 3 with the change in the log after-tax income between 1985 and 1988. Of course, this variable may be endogenous for the same reasons as our tax price variable. We can construct an instrument for it analogous 
to that used for our tax price variable (i.e., compute 1988 after-tax income using 1985 income data and 1988 tax structure). The estimates when the basic model is augmented with the difference in the log of after-tax income are reported in column (4). The inclusion of this variable does not affect the nature of our results. The coefficient on the tax price remains positive and significant - the estimated coefficient is 0.746 with a standard error of 0.143 . The coefficient on after-tax income is statistically significant -0.0525 with a standard error of 0.0171. The fact that increasing cash flow enhances business performance is consistent with earlier research which shows that liquidity constraints affect the decisions of small firms (see, e.g., Evans and Jovanovic [1989] and Holtz-Eakin, Joulfaian, and Rosen [1994a]).

Our basic specification allows for across-industry differences in rates of growth, but the effect of taxes is assumed to be independent of industry. Perhaps, though, firms operating in some industries are more tax sensitive than others. More specifically, the model in Section 2 indicated that tax responses depend upon production function parameters, and these may be expected to differ by industry. To address this issue, we augmented the basic specification with a series of terms interacting the change in the tax price with the various industry indicators. We found that, in general, tax price effects do not vary across industries. Only one of the coefficients was statistically significant. (In the service sector, the interaction had a point estimate of 1.37 with a t-statistic of 3.78.$)^{24}$ In magnitude, it was larger than the estimate without the interaction (reported in column (1) of Table 3), but the qualitative result was basically the same. $^{25}$

The theme emerging from our discussion of Table 3 is that changes in entrepreneurs' tax rates have a significant impact on the growth of their enterprises. As discussed earlier, however, one may wish to tighten the criteria for classifying Schedule $\mathrm{C}$ filers as entrepreneurs. To do so, we imposed the requirement that sole proprietors reported $\$ 500$ of gross business receipts and 
repeated our statistical analysis using this smaller (8,324 observations), more select sample. The basic tenor of our results is unchanged; $\triangle \ln (T A X P R I C E)$ continues to be positive $(0.747)$ and statistically significant (s.e. $=0.156)$ As further checks, we raised the minimum threshold to $\$ 1,000$ of business receipts, and then to $\$ 5,000$. In each case, the estimated coefficients remain positive and significant, although the magnitudes diminish to 0.725 and 0.641 , respectively. ${ }^{26}$

\subsection{Tax Rates and Survivor Probabilities}

As noted above, the results in Table 3 are generated by a two-step procedure whose first stage is a probit equation for the probability that an individual survives as a sole proprietor from 1985 to 1988 . This specification does not constrain the tax price to have the same sign in the survival and receipts growth equation. Our theoretical model indicates that there is no reason to impose such a constraint. While an increase in the tax price may increase receipts growth conditional on remaining in business, at the same time, it may also make the salaried sector more attractive. This renders the ultimate impact ambiguous. Although we have viewed this equation primarily as a means for generating consistent estimates of the receipts growth model, it is of independent interest. Specifically, the probit equation reveals how the survival rate in selfemployment depends on tax rates. ${ }^{27}$ The probit coefficients are reported in column (1) of Table 4.

The coefficient on the change in the log of the tax price is negative $(-0.137)$ and exceeds its standard error by only a factor of 1.3. Hence, in our data, higher taxes exert their major effect on the growth rates of existing firms as opposed to their survival probabilities.

Recall that the probit model is estimated by instrumental variables because of the endogeneity of the tax price. Column (2) reports the results when endogeneity is ignored. Like its counterpart in the IV model of column (1), the coefficient on the tax price is negative. However, it is larger in absolute value and it is statistically significant (the coefficient exceeds its 
standard error by a factor of almost 5). Hence, failing to correct for endogeneity leads to the incorrect inference that increases in tax rates increase the probability of surviving as an entrepreneur.

This finding leads to a concern about a technical issue. In the probit context, the instrumental variables procedure generates consistent estimates only if the error terms in both the first and second stage equations are joint normally distributed, and both equations are correctly specified. In a linear model the conditions are considerably less stringent. The right hand side variables in the first stage equation have to be uncorrelated with the error term in the second stage equation, but consistent estimates may be obtained even if some variables that belong in the first stage equation are omitted. Therefore, despite the well-known limitations of the linear probability model, it seemed worthwhile to use it to check our estimates. The coefficient on the tax price is more precisely estimated in the linear probability model than in the probit model. The coefficient, -0.0797 , exceeds its standard error by almost a factor of three. However, the implied elasticity of the probability of survival with respect to the tax price, evaluated at the means, is essentially zero, -0.012 . Hence, while strong assumptions are needed to deal with endogeneity in the probit model, the basic qualitative result holds when the analysis is done using the more robust linear probability model— - tax rates do not greatly affect survivorship probabilities.

There are not too many results in the literature to which we can compare this finding. The most directly comparable study is Bruce [1999], whose analysis of United States panel data indicated that higher tax rates reduce the probability of exiting self-employment. Gentry and Hubbard [2000] examined a different type of transition, entry into self-employment, and found that the probability of entry increases when tax rates are less progressive. The remaining related studies we have found in effect analyze the contemporaneous relationship between the propensity to be self-employed and taxes, either at the aggregate or individual level. Parker 
[1996], Blau [1987], and Fairlie and Meyer [1999] examined the time series relationship between aggregate self-employment rates and tax rates. Parker (with U.K. data) and Blau (with United States data) found that higher tax rates encourage self-employment. ${ }^{28}$ On the other hand, Fairlie and Meyer's examination of United States data over the course of the twentieth century indicated no relationship. Robson and Wren [1999] found a negative relationship between selfemployment rates and marginal tax rates in a panel study of OECD countries during the 1980s. Long's [1982] analysis of United States cross sectional data indicated that higher taxes are associated with a greater probability of being self-employed.

None of the above studies use tax return data; hence, it is of interest to re-estimate these earlier models using our data. Our sample allows us to estimate a model that is in the spirit of the studies that focus on the contemporaneous relationship between the propensity to be selfemployed and marginal tax rates. Specifically, we analyze the links between the probability that an individual is a sole proprietor and his or her tax price in the 1985 cross section. To begin, we estimate a simple probit in which the only right hand side variable is the logarithm of the individual's tax price. The results are in column (3) of Table 4. In column (4) we augment this model with the usual set of covariates. Note that the tax price variable goes from being negative and statistically significant in column (3) to positive and significant in column (4). This suggests that cross-sectional relationships between self-employment probabilities and tax rates are sensitive to the particular covariates included in the equation. This problem may be compounded if no correction is made for the endogeneity of the tax price, a task that is likely to be quite difficult in a single cross-section. 


\section{CONCLUSIONS}

Policymakers have long been concerned about the possible inhibiting effects of taxes on small businesses, but not much is known about the relationship between tax rates and business growth. In this paper, we have focused on the empirical relationship between a sole proprietor's personal income tax rate and the growth of the receipts from his enterprise. We examine tax return data for sole proprietors from before and after the Tax Reform Act of 1986 . We find that when a sole proprietor's marginal tax rate goes up, the rate of growth of his enterprise goes down. The elasticity of receipts with respect to the tax price (one minus the marginal tax rate) is about 0.84 . This implies, for example, that a decrease in the marginal tax rate levied on a sole proprietor from 50 percent to 33 percent would lead to an increase in his receipts by about 28 percent. Of course, entrepreneurs also operate in organizational forms other than sole proprietorships. Our results suggest that it would be worthwhile to explore whether taxes discourage the growth of such enterprises as well. 


\section{APPENDIX}

This appendix formalizes our framework for analyzing the effects of personal taxation on the growth and survival probabilities of entrepreneurial enterprises. As in the text, we first focus on how taxes affect the entrepreneur's input decisions and then deduce the implications for firm size.

To fix ideas, it is useful to revisit the derivation of the impact of taxation on individuals' decisions as wage-earners because the underlying forces are easily elucidated in this setting. Specifically, assume that individuals choose their labor supply, $e$ ("effort"), to maximize utility

$$
U(c, e)
$$

where $c$ is consumption. The budget constraint is

$$
c=w(1-\tau) e+A
$$

where $w$ is the wage, $\tau$ is the tax rate, and $A$ is non-labor income. Choosing $e$ to maximize (A.1) yields the familiar necessary condition for determining labor supply,

$$
U_{c}+w(1-\tau) U_{e}=0
$$

When the net wage changes due to, say, a reduction in taxes, then optimal effort changes as well:

$$
\frac{d e}{d w(1-\tau)}=\frac{-\left[U_{c}+w e U_{c c}+U_{e e}\right]}{w^{2} U_{c c}+2 w U_{c e}+U_{e e}} \gtrless 0,
$$

where subscripts denote partial derivatives. This is the textbook model of labor supply in which the conflict of income and substitution effects yields no firm prediction regarding whether effort will rise or fall. It is straightforward to show that

$$
\frac{d e}{d w(1-\tau)}>0 \Leftrightarrow 1-\alpha\left(\sigma_{c}+\sigma_{e}\right)>0
$$

where $\alpha \equiv \frac{w(1-\tau) e}{c}, \quad \sigma_{c} \equiv \frac{-U_{c c} c}{U_{c}}, \quad$ and $\sigma_{e} \equiv \frac{U_{e c} c}{U_{e}}$. 
We turn next to entrepreneurs. At the outset, we analyze decisions conditional on the entrepreneur always remaining in business; the possibility of exiting to wage-earning is introduced later. We assume that output of the entrepreneurial enterprise is determined by the production function $F(e, \ell)$, where we assume for simplicity that labor, $\ell$, is the only purchased input. $^{29}$ Normalizing the output price to unity and defining the "tax price," $\mu$, as one minus the tax rate, the entrepreneur's budget constraint is:

$$
c=\mu[F(e, \ell)-w \ell]+A
$$

The entrepreneur chooses $e$ and $l$ so as to maximize utility, yielding the pair of first-order conditions

$$
\begin{aligned}
& U_{c}(\mu)\left(F_{\ell}-w\right)=0, \text { and } \\
& U_{c}(\mu) F_{e}+U_{e}=0 .
\end{aligned}
$$

To determine the impact of a reduction in taxes, note that (A.7) implies $\frac{d \ell}{d \mu}=\frac{-F_{\ell e}}{F_{\ell \ell}} \frac{d e}{d \mu}$, so that the impact on hiring decisions is tied to the impact on the entrepreneur's own effort. Turning to the latter, the first-order conditions imply that

$$
\frac{d e}{d \mu}=\frac{-\left[U_{c} F_{e}+(F(e, \ell)-w \ell)\left(\mu F_{e} U_{c c}+U_{e c}\right]\right.}{-\mu U_{c}\left(\frac{F_{\ell e}^{2}}{F_{\ell \ell}}\right)+\mu U_{c} F_{e e}+\mu^{2} F^{2} U_{c c}+\mu F_{e} U_{c e}+\mu F_{\ell} U_{e c}+U_{e e}} .
$$

Not surprisingly, expression (A.9) is ambiguous. However, if (A.5) is satisfied, the substitution effect will dominate the income effect and a reduction in taxes will raise $e$. When is this likely to be the case? Intuitively, the greater the share of consumption financed by business profit $(\alpha)$, the greater will be the importance of the marginal utility of consumption to the decision to supply effort to the business. Also, the more rapidly the marginal utility of consumption declines, ceteris paribus, the less likely that additional profits will induce effort. 
To determine the implications for the effect of taxation on the receipts of the enterprise, recall that (because the output price is unity) gross receipts are given by $R=F(e, \ell)$. It follows that

$$
\frac{d R}{d \mu}=\left(\frac{-F_{\ell e} F_{e}}{F_{\ell \ell}}+F_{e}\right) \frac{d e}{d \mu} .
$$

Inspection of (A.10) indicates that the effect of taxes on receipts depends upon the impact on effort, but also upon the parameters of the production function. In any case, because $\frac{d e}{d \mu}$ is ambiguous, so is the effect on receipts.

We arrived at equation (A.10) by assuming that entrepreneurs will always remain in business. In fact, however, there is always the option of exiting to the wage-salary sector. Hence, we consider the impact of taxes on survival as well. Let $V^{e}$ denote the maximal utility achieved as an entrepreneur, and $V^{w}$ the corresponding maximal value as an employee. Then, the impact of taxes on the difference in utility, and hence the incentive to remain an entrepreneur, is

$$
\frac{d\left(V^{e}-V^{w}\right)}{d \mu}=U_{c}^{*}\left[F\left(e^{*}, \ell^{*}\right)-w \ell^{*}\right]-U_{c}^{+}\left(w e^{+}\right)
$$

where the superscripts ${ }^{*}$ and ${ }^{+}$indicate the optimal decisions as an entrepreneur and wage-earner, respectively. Without a priori information regarding marginal utility of consumption in each sector of the economy, the effect of taxes is ambiguous, as observed in the text. 


\section{NOTES}

1. A related question that has received some careful attention is whether taxes affect the propensity to be self-employed. Although not central to the present study, we present some evidence on this matter below.

2. Since it is an election year, it is unseemly to discuss an increase in tax rates.

3. Fazzari, Hubbard, and Peterson [1988] argue that corporate investment decisions are limited by lack of access to capital; Holtz-Eakin, Joulfaian, and Rosen [1994b] document the same phenomenon for sole-proprietorships.

4. See Section 179 of the Internal Revenue Code. For tax year 2000, the Section 179 expensing limit is $\$ 20,000$. In tax years 2001 and 2002, it will rise to $\$ 24,000$. In tax year 2003 and thereafter it will be $\$ 25,000$.

5. In contrast, if the dealer sells the art gallery itself, the income would be treated as a capital gain. Certain depreciable capital assets ("section 1231 assets") receive particularly favorable treatment. They receive capital gains treatment when the aggregate of the gains from their sale is positive, but ordinary treatment of aggregate losses; i.e., the loss limitations do not apply.

6. More specifically, we generally observe AMT preferences only for taxpayers subject to the AMT. From an operational point of view, it is very difficult to calculate tentative AMT when holding income constant. We also excluded dependent filers and individuals who changed marital status. This led to the deletion of 1,628 observations.

7. We required those who filed a Schedule C in 1985 to have positive values for gross receipts.

8. Modified AGI is the sum of AGI, excluded capital gains, excluded dividends, and excluded unemployment compensation.

9. The basic picture is unchanged if we include in our computations those who exited soleproprietorship between 1985 and 1988. The corresponding growth rate in this sample for the bottom 25 percent is -9.3 percent. The mean growth rates at the upper end range between 9.7 percent and 11.1 percent.

10. While there is no information on employment, there are data on the firm's wage bill, which allow one to study whether taxes affect the dichotomous decision of whether or not to hire labor. See Carroll, Holtz-Eakin, Rider, and Rosen [2000a].

11. For data sets focused on labor market issues, the key criterion has been whether the individual classifies him or herself as being primarily self-employed. However, the 
Characteristics of Business Owners data set created by the U.S. Census Bureau also uses a tax-based definition of entrepreneurship. (See Holmes and Schmitz [1991].)

12. This figure includes "business services" (advertising, management consulting, public relations, computer services, etc.) and "accounting and bookkeeping services."

13. We also estimated the model with a quartic in age, and found that it left the substantive results essentially unchanged. Taxpayers' ages are not reported on individual income tax forms. Ages are added to the Individual Tax File through the use of data provided by the Social Security Administration.

14. See Evans and Jovanovic [1989], Holtz-Eakin, Joulfaian, and Rosen [1994a, 1994b], and van Praag and van Ophem [1995] for evidence on the importance of liquidity constraints to entrepreneurial decision-making.

15. Of course, other conventional data sets also lack information on important components of capital income.

16. We compute our marginal tax rates using detailed tax calculators developed by the Office of Tax Analysis, U.S. Treasury and tailored for our panel. These calculators account for both the statutory rate schedule and the many implicit tax rates (e.g., the post-TRA86 phase-out of tax benefits associated with the 15 percent tax bracket and the personal exemption) that arise from special features of the tax code. Our marginal tax rates include the SECA (Self-Employment Contributions Act) tax, and the Social Security tax for wage-earners.

17. An endogenous component of changes in tax rates of particular interest is that stemming from tax evasion. One possibility is that a cut in tax rates reduces evasion, raises reported taxable income, and as a consequence raises observed marginal tax rates, ceteris paribus. Our instrumental variable is constructed to eliminate all behavior-based changes in marginal tax rates, including those associated with evasion. The possibility remains, however, that some of our estimated change in gross receipts is due to changes in reporting (as opposed to real) behavior.

18. The standard deviations of the percentage change in tax price from the lowest to the highest income quintile are as follows: 10.6, 10.2, 10.4, 14.7, 9.7.

19. Indeed, TRA86 embodied incentives to alter the organizational form of a business. The main thrust was to make taxation under the individual income tax (sole proprietorship, partnership, subchapter S corporation) more attractive relative to the corporation tax; see Carroll and Joulfaian [1995] or Plesko [1994]. Hence, TRA86 was more likely to induce "entry" than "exit."

20. Survival probability is related to initial size, as documented by Caves [1998]. Hence, in addition to the variables in equation (4.1), we include the logarithm of gross receipts in 1985. 
21. See Efron [1979] for a discussion.

22. While most demographic variables do not seem to be strongly correlated with changes in various characteristics of small firms, these variables are correlated with the probability that a given individual is an entrepreneur. See, e.g., Meyer [1990].

23. The omitted industry category includes transportation, construction, mining, agriculture, and miscellaneous other industries. They are grouped together because, on an individual basis, each accounts for a very small proportion of the observations.

24. An interesting exercise would be to see if the tax-price results are robust to dropping observations from the service sector altogether. However, as implied toward the bottom of Table 2, this would involve leaving out more than one-half the observations.

25. Our canonical specification also ignores across-state differences in business environments. For example, states differ in their regulatory and tax systems. To control for such differences, we added a set of dichotomous state variables to our basic specification. The inclusion of these controls had little effect on the tax-price coefficient.

26. An alternative concern is that some of our entrepreneurs are "too serious"; that is, our results may be unduly influenced by the presence of some very large sole proprietorships that are not representative of the small firms that are our focus. To investigate this possibility, we deleted the 10 percent of our sample reporting the largest gross receipts in 1985 (gross receipts greater than $\$ 803,600$ ). Qualitatively, this has very little effect. The estimated coefficient for the tax price remains positive (0.597) and statistically significant (standard error equal to 0.126 ).

Finally, to further hone our focus on serious, small entrepreneurs, we deleted both the top 10 percent as measured by gross receipts and the bottom 10 percent (gross receipts below $\$ 1,400)$. Again, there is little qualitative effect on our conclusions as the estimated coefficient and its standard error are 0.693 and 0.143 , respectively.

27. The organizational choice decision also depends on the tax rates applied to corporations, inter alia. These also changed as a consequence of the Tax Reform Act of 1986. (See Gordon and MacKie-Mason [1997].) However, the change applied to all individuals, and hence does not require any special control in our analysis.

28. This finding is generally rationalized by considerations not included in our simple theoretical model. Higher tax rates are associated with higher returns to tax evasion or offer "insurance" against entrepreneurial risk. As already noted, our model can generate a positive correlation between tax rates and self-employment probabilities without appealing to such factors.

29. We focus on a single purchased input for expositional clarity alone. Our approach is readily generalized to situations in which entrepreneurial ventures use multiple purchased inputs. 


\section{REFERENCES}

Auten, Gerald and Janette Wilson. 1999. "Sales of Capital Assets Reported on Individual Income Tax Returns, 1985," SOI Bulletin (Spring): 113-136.

Blau, David M. 1987. "A Time-Series Analysis of Self-Employment in the United States," Journal of Political Economy, 95: 445-467.

Bruce, Donald. 1999. "Taxes and Small Business Failure: Evidence from the Self-Employed," Working Paper, Center for Business and Economic Research. Knoxville, TN: University of Tennessee (August).

Carroll, Robert, Douglas Holtz-Eakin, Mark Rider and Harvey S. Rosen. 2000a. "Income Taxes and Entrepreneurs' Use of Labor," Journal of Labor Economics, 18(2) (April): 324-351.

Carroll, Robert, Douglas Holtz-Eakin, Mark Rider, and Harvey S. Rosen. 2000b. "Entrepreneurs, Income Taxes, and Investment." In Joel B. Slemrod (ed.), Does Atlas Shrug? New York: Russell Sage Foundation, pp. 427-455.

Carroll, Robert and David Joulfaian. 1995. "Taxes and Corporate Choice of Organizational Form," mimeo. Washington, DC: U.S. Department of Treasury.

Caves, Richard E. 1998. "Industrial Organization and New Findings on The Turnover and Mobility of Firms," Journal of Economic Literature (December): 1947-1982.

Efron, B. 1979. "Bootstrap Methods: Another Look at the Jacknife," The Annals of Statistics, 7(11): 1-26.

Engen, Eric and Jonathan Skinner. 1996. “Taxation and Economic Growth," National Tax Journal, 49 (December): 617-642.

Evans, David S. 1987. “Tests of Alternative Theories of Firm Growth," Journal of Political Economy, 95 (August): 657-674.

Evans, David S. and Boyan Jovanovic. 1989. "An Estimated Model of Entrepreneurial Choice Under Liquidity Constraints," Journal of Political Economy, 97: 808-827.

Fairlie, Robert W. and Bruce D. Meyer. 1999. "Trends in Self-Employment among White and Black Men: 1910-1990,” NBER Working Paper No. 7182. Cambridge, MA: National Bureau of Economic Research, June.

Feenberg, Daniel. 1987. "Are Tax Price Models Really Identified: The Case of Charitable Giving," National Tax Journal, 40(4) (December): 629-633.

Gentry, William M. and R. Glenn Hubbard. 1998. "Why Do the Wealthy Save So Much?: Saving and Investment Decisions of Entrepreneurs," Working Paper, School of Business. New York: Columbia University, July. 
Gentry, William M. and R. Glenn Hubbard. 2000. "Tax Policy and Entrepreneurial Entry," American Economic Review, 90 (May): 283-287.

Gordon, Roger and Jeff MacKie-Mason. 1997. "Taxes and Choice of Organizational Form," Journal of Finance (June).

Hamilton, Barton Hughes. 2000. "Does Entrepreneurship Pay? An Empirical Analysis of the Returns to Self-Employment," Journal of Political Economy, 108 (June): 604-631.

Heckman, James J. 1979. "Sample Selection Bias as a Specification Error,” Econometrica, 47: 153-61.

Holmes, T. J. and J.A. Schmitz. 1991. "Measuring Small Business Dynamics When Owners and Their Businesses Can Be Separately Identified," mimeo. Hanover, NH: Dartmouth College.

Holtz-Eakin, Douglas, David Joulfaian, and Harvey S. Rosen. 1994a. "Sticking It Out: Entrepreneurial Survival and Liquidity Constraints," Journal of Political Economy (February): 53-75.

Holtz-Eakin, Douglas, David Joulfaian, and Harvey S. Rosen. 1994b. "Entrepreneurial Decisions and Liquidity Constraints," RAND Journal of Economics, 23(2) (Summer): 334-347.

Long, James E. 1982. "The Income Tax and Self-employment," National Tax Journal, 35: $31-42$.

Meyer, Bruce. 1990. "Why Are There So Few Black Entrepreneurs," NBER Working Paper No. 3537. Cambridge, MA: National Bureau of Economic Research.

Parker, Simon C. 1996. "A Time Series Model of Self-Employment,” Economica, 63: 459-475.

Plesko, George. 1994. "The Role of Taxes in Organizational Choice: S-Conversions After the Tax Reform Act of 1986," mimeo. Boston, MA: Northeastern University.

Rigby, Larry. 1996. "What I'd Do With My Capital Gains,” Wall Street Journal, April 30, p. A18.

Robson, Martin T. and Colin Wren. 1999. "Marginal and Average Tax Rates and the Incentive for Self-Employment," Southern Economic Journal, 65: 757-773.

van Praag, C. Mirjam and Hans van Ophem. 1995. "Determinants of Willingness and Opportunity to Start as an Entrepreneur," Kyklos, 48: 513-540. 
Table 1. Transitions in Income-Generating Activity for Sole-Proprietors in 1985: 1985 versus $1988^{\mathrm{a}}$

\begin{tabular}{lcc}
\hline & $\begin{array}{c}\text { Schedule C and } \\
\text { No Wage-Salary } \\
\text { Income in 1985 }\end{array}$ & $\begin{array}{c}\text { Schedule C and Wage- } \\
\text { Salary Income in 1985 }\end{array}$ \\
\hline Exit Sole Proprietorship & 0.0859 & 0.212 \\
To Wage-Salary only & 0.0290 & 0.126 \\
& $(33.8 \%)$ & $(59.3 \%)$ \\
To Business Income ${ }^{\mathrm{b}}$ only & 0.0238 & 0.00520 \\
To Wage-Salary and Business Income & $(27.7 \%)$ & $(2.4 \%)$ \\
& 0.0226 & 0.0791 \\
To Neither Wage-Salary nor Business Income & $(26.4 \%)$ & $(37.4 \%)$ \\
& 0.0105 & 0.0017 \\
\hline
\end{tabular}

${ }^{a}$ Each entry shows the fraction of sole proprietors in 1985 who ceased filing a Schedule C in 1988, and in 1988 were engaged in the activity in the corresponding row. The figures in parentheses show the percentage of individuals in each column who are in the corresponding row.

${ }^{\mathrm{b}}$ Business Income is income from a partnership or Subchapter S Corporation. 
Table 2. Sample Statistics ${ }^{\mathrm{a}}$

\begin{tabular}{|c|c|c|}
\hline & $(1)^{b}$ & $(2)^{\mathrm{c}}$ \\
\hline$\Delta \ln ($ GRECEIPTS) (log-difference in gross receipts) & -- & $\begin{array}{c}0.332 \\
(0.186)\end{array}$ \\
\hline$\Delta \ln (T A X P R I C E)(\text { log-difference in tax price })^{\mathrm{d}}$ & $\begin{array}{c}0.124 \\
(0.209)\end{array}$ & $\begin{array}{c}0.127 \\
(0.214)\end{array}$ \\
\hline$A G E$ (age $\mathrm{x} 10^{-2}$ in years) & $\begin{array}{c}0.414 \\
(0.786)\end{array}$ & $\begin{array}{c}0.416 \\
(0.0781)\end{array}$ \\
\hline$A G E^{2}$ (age $\times 10^{-2}$ squared) & $\begin{array}{c}0.177 \\
(0.0650)\end{array}$ & $\begin{array}{c}0.179 \\
(0.0648)\end{array}$ \\
\hline CAPINC (interest and dividend income $\times 10^{-6}$ ) & $\begin{array}{c}0.0501 \\
(0.353)\end{array}$ & $\begin{array}{c}0.0524 \\
(0.373)\end{array}$ \\
\hline $\operatorname{MARRIED}(=1$, if married $)$ & $\begin{array}{c}0.914 \\
(0.280)\end{array}$ & $\begin{array}{c}0.916 \\
(0.278)\end{array}$ \\
\hline DEPENDENTS (number of dependents $\times 10^{-1}$ ) & $\begin{array}{c}0.161 \\
(0.133)\end{array}$ & $\begin{array}{c}0.162 \\
(0.134)\end{array}$ \\
\hline$M F G$ (=1, if manufacturing sector) & $\begin{array}{c}0.0238 \\
(0.152)\end{array}$ & $\begin{array}{c}0.0233 \\
(0.151)\end{array}$ \\
\hline WHOLESALE (=1, if wholesale trade sector) & $\begin{array}{c}0.0238 \\
(0.152)\end{array}$ & $\begin{array}{c}0.0229 \\
(0.150)\end{array}$ \\
\hline $\operatorname{RETAIL}(=1$, if retail trade sector) & $\begin{array}{c}0.110 \\
(0.313)\end{array}$ & $\begin{array}{c}0.104 \\
(0.306)\end{array}$ \\
\hline FINANCE (=1, if finance sector $)$ & $\begin{array}{c}0.111 \\
(0.314)\end{array}$ & $\begin{array}{c}0.111 \\
(0.315)\end{array}$ \\
\hline SERVICE (=1, if service sector) & $\begin{array}{c}0.543 \\
(0.498)\end{array}$ & $\begin{array}{c}0.555 \\
(0.497)\end{array}$ \\
\hline $\mathrm{N}$ & 8,675 & 6,817 \\
\hline
\end{tabular}

${ }^{a}$ Table entries are means and, in parentheses, standard deviations.

${ }^{\mathrm{b}}$ Column (1) contains statistics for all individuals in our sample who were sole proprietors with positive receipts in 1985 regardless of whether they were also sole proprietors in 1988.

${ }^{\mathrm{c}}$ Column 2 contains statistics for the subset of those individuals who were sole proprietors with positive receipts in both 1985 and 1988 .

${ }^{\mathrm{d}}$ The tax price is defined as one minus the marginal tax rate. 
Table 3. Analysis of Receipts Growth ${ }^{\mathrm{a}}$

\begin{tabular}{|c|c|c|c|c|}
\hline & (1) & (2) & (3) & (4) \\
\hline INTERCEPT & $\begin{array}{l}-0.948 \\
(0.574)\end{array}$ & $\begin{array}{l}-0.712 \\
(0.0661)\end{array}$ & $\begin{array}{l}-0.977 \\
(0.583)\end{array}$ & $\begin{array}{l}-0.989 \\
(0.572)\end{array}$ \\
\hline$\triangle \ln (T A X P R I C E)$ & $\begin{array}{c}0.836 \\
(0.149)\end{array}$ & $\begin{array}{c}0.915 \\
(0.138)\end{array}$ & $\begin{array}{c}0.928 \\
(0.156)\end{array}$ & $\begin{array}{c}0.746 \\
(0.143)\end{array}$ \\
\hline$A G E$ & $\begin{array}{r}0.268 \\
(2.80)\end{array}$ & --- & $\begin{array}{r}0.370 \\
(2.83)\end{array}$ & $\begin{array}{r}0.489 \\
(2.78)\end{array}$ \\
\hline$A G E^{2}$ & $\begin{array}{l}-0.788 \\
(3.38)\end{array}$ & --- & $\begin{array}{l}-0.837 \\
(3.39)\end{array}$ & $\begin{array}{l}-0.988 \\
(3.33)\end{array}$ \\
\hline CAPINC & $\begin{array}{l}-0.128 \\
(0.137)\end{array}$ & --- & $\begin{array}{l}-0.0827 \\
(0.134)\end{array}$ & $\begin{array}{l}-0.114 \\
(0.131)\end{array}$ \\
\hline MARRIED & $\begin{array}{c}0.0107 \\
(0.0737)\end{array}$ & --- & $\begin{array}{c}0.00672 \\
(0.0747)\end{array}$ & $\begin{array}{c}0.0135 \\
(0.0735)\end{array}$ \\
\hline DEPENDENTS & $\begin{array}{c}0.150 \\
(0.174)\end{array}$ & --- & $\begin{array}{c}0.156 \\
(0.176)\end{array}$ & $\begin{array}{c}0.152 \\
(0.173)\end{array}$ \\
\hline$M F G$ & $\begin{array}{c}0.464 \\
(0.129)\end{array}$ & --- & $\begin{array}{c}0.454 \\
(0.132)\end{array}$ & $\begin{array}{c}0.456 \\
(0.129)\end{array}$ \\
\hline WHOLESALE & $\begin{array}{l}-0.0127 \\
(0.138)\end{array}$ & --- & $\begin{array}{l}-0.0306 \\
(0.139)\end{array}$ & $\begin{array}{l}-0.0246 \\
(0.136)\end{array}$ \\
\hline RETAIL & $\begin{array}{c}0.132 \\
(0.0867)\end{array}$ & --- & $\begin{array}{c}0.123 \\
(0.0873)\end{array}$ & $\begin{array}{c}0.121 \\
(0.0855)\end{array}$ \\
\hline FINANCE & $\begin{array}{c}0.115 \\
(0.0832)\end{array}$ & --- & $\begin{array}{c}0.105 \\
(0.0834)\end{array}$ & $\begin{array}{c}0.118 \\
(0.0828)\end{array}$ \\
\hline SERVICE & $\begin{array}{c}0.347 \\
(0.0581)\end{array}$ & --- & $\begin{array}{c}0.338 \\
(0.0592)\end{array}$ & $\begin{array}{c}0.338 \\
(0.0576)\end{array}$ \\
\hline EARNINGS & --- & --- & $\begin{array}{l}-0.186 \\
(0.0831)\end{array}$ & --- \\
\hline$\Delta \ln (I N C O M E)$ & --- & --- & --- & $\begin{array}{c}0.0525 \\
(0.0171)\end{array}$ \\
\hline Inverse Mill's Ratio & $\begin{array}{l}2.18 \\
(0.160)\end{array}$ & $\begin{array}{l}2.13 \\
(0.162)\end{array}$ & $\begin{array}{l}2.22 \\
(0.165)\end{array}$ & $\begin{array}{l}2.16 \\
(0.158)\end{array}$ \\
\hline $\mathrm{N}$ & 6,817 & 6,817 & 6,817 & 6,817 \\
\hline
\end{tabular}

${ }^{a}$ The left-hand side variable in each equation is the log-difference in gross receipts between 1985 and1988. Estimation is by instrumental variables, treating $\triangle \ln (T A X P R I C E)$ as endogenous. Standard errors, which are in parentheses, are computed by bootstrapping methods. Variables are defined in Table 1, except for EARNINGS (household earnings in 1985) and $\Delta \ln (I N C O M E)$ (log difference in net income between 1985 and 1988). The latter variable is treated as endogenous. 
Table 4. Probit Analysis of Self-Employment Decisions ${ }^{\mathrm{a}}$

\begin{tabular}{|c|c|c|c|c|}
\hline & $(1)^{b}$ & $(2)^{\mathrm{c}}$ & $(3)^{d}$ & $(4)^{d}$ \\
\hline INTERCEPT & $\begin{array}{l}-1.18 \\
(0.447)\end{array}$ & $\begin{array}{l}-1.26 \\
(0.425)\end{array}$ & $\begin{array}{l}-0.0994 \\
(0.141)\end{array}$ & $\begin{array}{l}-5.32 \\
(0.402)\end{array}$ \\
\hline$\triangle \ln (T A X P R I C E)$ & $\begin{array}{l}-0.137 \\
(0.109)\end{array}$ & $\begin{array}{l}-0.401 \\
(0.0836)\end{array}$ & -- & -- \\
\hline $\ln (T A X P R I C E)$ & -- & -- & $\begin{array}{l}-0.103 \\
(0.0335)\end{array}$ & $\begin{array}{l}0.657 \\
(0.0574)\end{array}$ \\
\hline$A G E$ & $\begin{array}{l}-0.268 \\
(2.15)\end{array}$ & $\begin{array}{c}-0.0453 \\
(2.13)\end{array}$ & -- & $\begin{array}{c}2.40 \\
(1.50)\end{array}$ \\
\hline$A G E^{2}$ & $\begin{array}{r}0.803 \\
(2.58)\end{array}$ & $\begin{array}{l}0.612 \\
(2.59)\end{array}$ & -- & $\begin{array}{l}-1.63 \\
(1.84)\end{array}$ \\
\hline CAPINC & $\begin{array}{l}-0.0565 \\
(0.0519\end{array}$ & $\begin{array}{l}-0.0464 \\
(0.0454)\end{array}$ & -- & $\begin{array}{l}0.240 \\
(0.0296)\end{array}$ \\
\hline MARRIED & $\begin{array}{c}0.0148 \\
(0.0604)\end{array}$ & $\begin{array}{c}0.0220 \\
(0.0603)\end{array}$ & -- & $\begin{array}{c}0.492 \\
(0.0425)\end{array}$ \\
\hline DEPENDENTS & $\begin{array}{l}-0.0834 \\
(0.149)\end{array}$ & $\begin{array}{l}-0.0720 \\
(0.134)\end{array}$ & -- & $\begin{array}{l}-0.253 \\
(0.103)\end{array}$ \\
\hline$M F G$ & $\begin{array}{c}0.0440 \\
(0.112)\end{array}$ & $\begin{array}{l}0.0393 \\
(0.109)\end{array}$ & -- & $\begin{array}{r}7.01 \\
(87.2)\end{array}$ \\
\hline WHOLESALE & $\begin{array}{l}-0.259 \\
(0.106)\end{array}$ & $\begin{array}{l}-0.265 \\
(0.108)\end{array}$ & -- & $\begin{array}{r}7.03 \\
(86.9)\end{array}$ \\
\hline RETAIL & $\begin{array}{l}-0.0994 \\
(0.0490)\end{array}$ & $\begin{array}{c}-0.118 \\
(0.0590)\end{array}$ & -- & $\begin{array}{l}3.88 \\
(0.144)\end{array}$ \\
\hline FINANCE & $\begin{array}{l}-0.0875 \\
(0.0507)\end{array}$ & $\begin{array}{l}-0.0938 \\
(0.0597)\end{array}$ & -- & $\begin{array}{r}7.05 \\
(38.8)\end{array}$ \\
\hline SERVICE & $\begin{array}{c}0.0798 \\
(0.0389)\end{array}$ & $\begin{array}{c}0.0830 \\
(0.0423)\end{array}$ & & $\begin{array}{c}4.44 \\
(0.108)\end{array}$ \\
\hline$R_{85}$ & $\begin{array}{c}0.192 \\
(0.00731)\end{array}$ & $\begin{array}{c}0.197 \\
(0.0069)\end{array}$ & -- & --- \\
\hline $\mathrm{N}$ & 8,675 & 8,675 & 31,034 & 31,034 \\
\hline
\end{tabular}

${ }^{a}$ Probit Estimates. Figures in parentheses are standard errors. $\mathrm{R}_{85}$ denotes gross receipts and the other variables are as defined in Table 1.

${ }^{\mathrm{b}}$ Column (1) is estimated over the sample of individuals who were sole proprietors in 1985. The left hand side variable is one if the individual was also a sole proprietor in 1988 and zero otherwise. The estimation is by instrumental variables, with the change in the log of tax price treated as endogenous.

${ }^{\mathrm{c}}$ Column (2), like column (1), estimates the probability of surviving as a sole proprietor from 1985 to 1988 . However, the change in the log of the tax price is not instrumented.

${ }^{\mathrm{d}}$ Columns (3) and (4) are estimated over the sample of sole proprietors and wage-earners in 1985. The left hand side variable is one if the individual was a sole proprietor in 1985 and zero otherwise. 